\title{
Revolutionary Games and repressive tolerance: on the hopes and limits of ludic citizenship
}

\author{
Benjamin Shepard \\ Human Services Dept., City University of New York \\ bshepard@CityTech.Cuny.Edu
}

\begin{abstract}
This essay considers examples of boisterous game play, including ludic movement activity and humour in the context of the Occupy Wall Street movement in the USA. This form of autoethnography makes use of the researcher's feelings, inviting readers into the personal, emotional subjectivities of the author. In this case, the author explores games, play, and humour highlighting a few of the possibilities and limits of play as a mechanism of social change, looking at the spaces in which it controls and when it liberates. While play has often been relegated to the sports field and the behaviour of children, there are other ways of opening spaces for play for civic purposes and political mobilization. The paper suggests play as a resource for social movements; it adds life and joyousness to the process of social change. Without playful humour, the possibilities for social change are limited.
\end{abstract}

Keywords: play, Occupy Wall Street, Marx, Burning Man, pie fights.

\section{Introduction}

Art and activism overlap in countless ways throughout the history of art and social movements. This essay considers the ways games, humour and play intervene and support the process. Here, social reality is imagined as a game, in which social actors play in irreverent, often humorous ways. Such activity has multiple meanings. For the purposes of this essay, play can be thought of as a spirit, which encompasses theatrical presentation as improvisation, motion, and an ethos of action, eruption and liberty (Schechner 2002: 79). But it is also paradoxical, sometimes pushing forward, sometimes backward between liberatory and repressive purposes. In its less formal incarnations, play can involve a hoola-hooping by the pool or poetry readings in the park. From time to time, it departs from the mundane, expanding into a status quo -threatening endeavour offering the possibility for emancipation from pain and liberation from alienating reified social 
relations. People are only free when they play, posits Georg Lukács, citing Schiller's famous lines on aesthetic education in History and Class Consciousness (1968: 138).

A sense of humour only adds to the process, adding a sense of festivity and release, freedom and surprise. "By its repudiation of the possibility of suffering," Sigmund Freud suggests, humour "takes its place in the great series of methods devised by the mind of man for evading the compulsion to suffer" (quoted in Morreall 1987: 113). Connected with social movements, subversive humour and pleasure disrupt monotony, liberate, and disarm systems of power (Critchley 2002; Holt 2008; Morreall 1987; Sanders 1996). Through humour and play, social actors challenge the rules of game of modern living, highlighting alternate ways of imaging social reality. While the concepts of humour, play, and fun differ and should not be used interchangeably, they also overlap in instructive ways. "Understanding humor as play helps counter the traditional objections to it and reveals some of its benefits, including those it shares with philosophy itself," notes John Morreall (2012). "Sudden glory" is the disposition of reacting to pain or sadness with a surprising laugh. Such disruptions are similar to the mechanisms of play and humour (Sanders 1996). More often than not laughter can be seen as a form of ridicule (Bogad 2005). "We have hatred for this evil, we have joy in seeing it in him who is deserving of it; and when that comes upon us unexpectedly, the surprise of wonder is the cause of our bursting into laughter..." notes Morreall (2012), suggesting such humour can be understood in terms of theories of superiority, relief, incongruity, play, and comedy. A pressure valve is released when we laugh and play, yielding distinct and overlapping feelings (Morreall 2012). The conceptual focus in this essay is on the humorous aspects of play as it is deployed in the specific contemporary context of social movements in New York City, rather than offering a clear definitional distinction between humour, play and game across all cultures and histories.

This essay considers the ways humour overlaps with examples of boisterous game play, including ludic movement activity. To do so, the essay deploys an autoethnographic narrative, making use of the researcher's feelings, thoughts, and reflections as subject of consideration in and of themselves in combination with other data, including second hand and historical sources. It is an autobiographical form of writing, inviting readers into the personal, emotional subjectivities of the author (Ellis and Bochner 2000). Such writing connects multiple layers of analysis, linking the cultural with the personal, moving backward and forward between observation of individual and larger social forces (Ellis and Bochner 2000). Autoethnographers point their gaze "first through an ethnographic wide-angle lens, focusing outward on social and cultural aspects of the personal experience; then they look inward, exposing a vulnerable self that is moved by and may move through, refract and resist cultural interpretations" (Ellis and Bochner 2000: 739). Yet, rather than allow the writer's voice to become central, auto-ethnography offers a view of the writer's own subjectivities, biases, and perspectives in relation to larger questions so the reader can see voice as a compliment to the larger cultural narrative at play (Trahar 2009).

In this case, I explore games, play, and humour highlighting a few of the possibilities and limits of play as a mechanism of social change. I first started thinking about play in social movements when the city in which I live, New York, officially sought to cut down on such practices through a new mayor's Temperance like Quality of Life Campaign in the mid-1990s (Shepard 2009). From performance art to street activism and John F. Kennedy Jr.'s romps through Central Park, creative outlets for play seem to define the contours of public space and private life in New York City. It seemed to be everywhere. And like the city itself, community organizing here took on countless ludic dimensions. Over and over, it helped open spaces for civic purposes and political mobilization, allowing people to meet and occupy public space in meaningful ways. 
Play is a resource for social movements; it adds life and joyousness to the process of social change. Without playful humour, the possibilities for social change are often limited, opportunities for transformation and release diminished.

The essay utilizes my own experience as a participant and observer of social movements that make use of play, contending that humour helps social actors to enjoy the process of social change, while communicating to multiple publics. Play and its humorous aspects have long been a part of social movements, extending from Dada to Surrealism, Situationism to ACT UP and Occupy (Shepard 2011). Through case examples from recent social movements in New York City, the essay explores how play is embedded in multiple creative activist practices.

\section{Social movements and games}

My experience with the subversive qualities of games began as a grade school kid who played football. Here, this game involved a barrage of obnoxious jokes aimed at all levels of authority; it also supported them. Repressive and liberatory, the game was vexing. It helped me see the limits of group think as people just went along as the game skirted codes of morality, while it emulated the highly competitive features of capitalism, much the same way that "war games" do in video games (Marcuse 1969; Wark 2007). Yet, there was another side to it. Watching football and its irreverent, often humorous grasp on politics, culture and entertainment, I became more and more aware of the possibilities of hijacking the mechanisms of the game. Over the years, my views of the game-like dimensions of the modern world became more and more complicated as a participant in social movements which looked to ludic play and games to help us re-imagine the rules of modern living. The non-competitive games of the Surrealist Movement offered a route away from the mechanics of capital, while members of the Occupy Movement reframed the game of modern capitalism in terms of a baseball game, bought and controlled by "Tax Dodgers". A working group of the movement imagined its effort in terms of what they termed "Revolutionary Games" (henceforth RevGames). Recognizing modern living as a gaming space akin to Plato's cave (Turkle 2011; Wark 2007), the key axiom of the RevGames working group is that winning on the terms of Capitalism and Empire is impossible; instead players strive to "emancipate our networks from the Game-Cave," notes Atchu! (2012), the pseudonym of a member of the RevGames working group. The point, of course, is that we all play the game (or at least we try to). Yet, sometimes the further we move into the game, the murkier the distance between the cave and the outside world (Wark 2007). So, we have to change the way the game is played. Others with Time's Up!, an environmental activist group, utilized highly theatrical bike rides among a community of friends to challenge the rules of urban traffic flow. Here the use of playful interventions helped satirize the limits of the rationalized mode of politics, simultaneously offering alternatives built around community organizing, autonomous movements, affinity groups, friendship networks, civic participation, creativity, social action, and flow. In this way, ludic activity served as a form of pleasure activism, in which social eros becomes a part of the process. There are thus many ways to play the game.

Whether highly participatory, expressive or repressive, games are not neutral activities. We can play them just as much as we may come to feel that we are played by the game. They have deep roots in social movements. Much of the contemporary ludic spirit of movement practices date back to Dada, Surrealism, and Situationism. Civil Rights activists in the US danced in the face of Jim Crow era social controls. The Youth International Party, the Yippies, made use of the prank as a means of political protest (Shepard 2011). Playful pranks served as a way to intrigue 
and seduce, lull and invite people into the process of social change, bringing humour into the discourse of progressive politics in unprecedented ways (Duncombe 2007). The social movements in the wake of AIDS and global justice struggles have built on this legacy.

\section{Revolutionary Games}

Shortly after the Occupy Wall Street (OWS) movement began in September 2011, anthropologist David Graeber (2011) commented in an interview on the game-like dimensions of the movement's struggle. "[E]everything is really about administration and control... power is diffused across networks without any clear us versus them," argued Graeber. "[T]hat reality is whatever you can convince people of, everything is strategic games whereby everybody is trying to dominate everybody else..." (2011). Yet the idea of viewing the public political space as a game that could be played became interesting not only as a metaphor for the non-seriousness of top-down political manoeuvres, but also a literal source of inspiration for activists struggling against this status quo of "strategic games".

Although different community groups have been occupying and disrupting spaces for generations, the Occupy Wall Street (OWS) movement began on 17 September 2011 when a group built a community in a publicly owned private space known as Zuccotti Park in the financial district, where they ate, slept, experimented, created a library, held spokes-councils, organized unpermitted marches opening up a conversation about income inequality and a critique of the distribution of wealth. Doing so they changed policies, as well as the cultural conversation, inviting everyone into the dialogue. For Mickey Z (2014: 7) the action helped him move. "Like a human may have done hundreds or even thousands of years ago, I followed the drumbeat through unfamiliar terrain until I found my tribe." Here those involved would "imagine an alternative form of human culture, and begin the process of making it happen," (Z 2014: 9). Tribes would wander from around the globe (Maffesoli 1996; Writers for the 99\% 2011).

Countless affinity groups and projects got involved. For example, a group of OWS members formed what they called the Revolutionary Games Working Group. "We are a collective that builds creative, revolutionary, and non-violent games online and in public spaces everywhere" (Revolutionary Games 2012). They met once a week at the Yippie Cafe on Bleecker Street, home of the Youth International Party, which had been bringing play and boisterous humour to activist settings since the late 1960s. The Yippies saw their movement and its effort to subvert the powers that be as a tremendous joke, but hopefully a little funnier than those in power, who they hoped to take down a notch or two through antic, mocking slapstick, a few pies, and perhaps a snarl (Sanders 1996).

On 17 January 2012, the Revolutionary Games Working Group debuted with "\#Glamarchy", "glitter-bombing oppression everywhere" (Atchu! 2012). The group started glitter bombing political opponents much like the Yippies used to use pies and political jokes as means of political resistance. Using the twitter handle @ OccupywallstreetNYC they invited other occupiers to glitter bomb political authorities, whom they considered to be their oppressors. On one notable occasion, a member of the Occupy group in Charlotte, North Carolina glitter bombed one of the most conservative of the Republicans running for President, Rick Santorum.

In April 2012, RevGames organized a number of street actions, including a protest with toy figures, carrying occupy signs and slogans. It was hard not to laugh when the real police arrived at the protest only to see toys lined up holding placards and protest symbols. The incongruity theory of humour helps us understand the workings of such a moments. Here, the Teddies seemed 
primarily set up as an incongruous representation of citizens, opening up both surprise, a feeling of the strange and thus of humour.
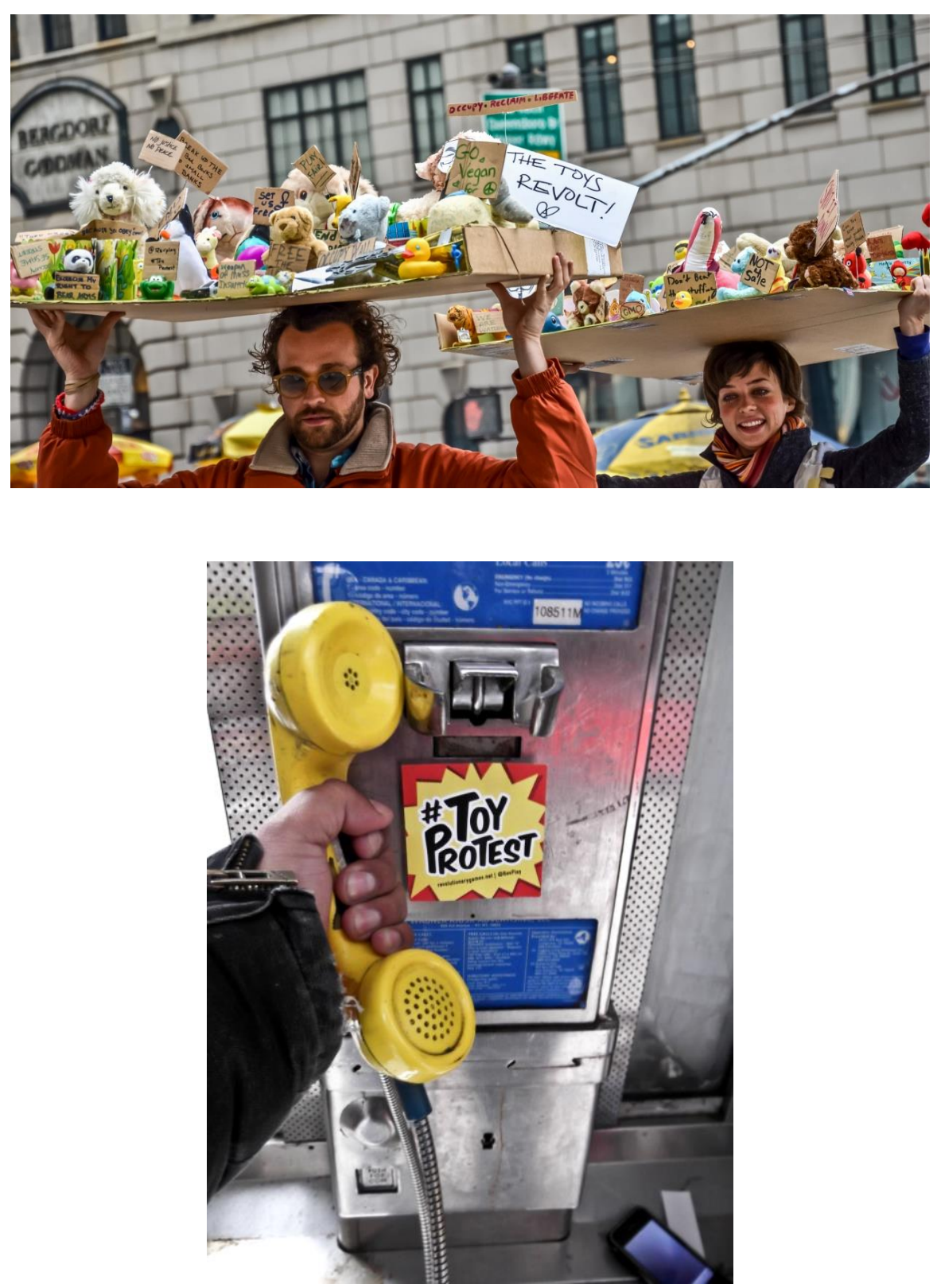


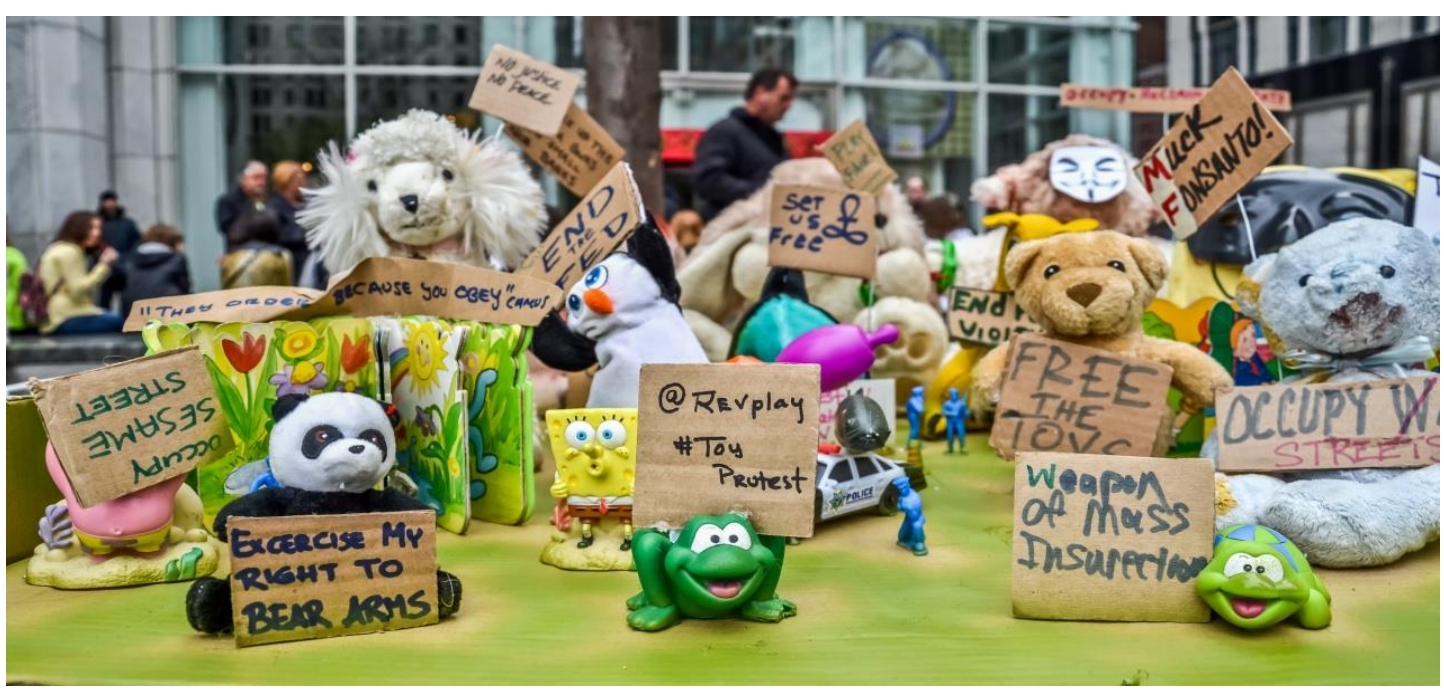

Figure 1. Toy Protest organized by Revolutionary Games, April 2012 (C) Erik McGregor.

The group's next prank was "Who Are You In Bed With?", a riff on an iconic 1960's era action. Here, the group invited people to expand John and Yoko's bed-in action for Peace on the streets. "We spread stickers everywhere on MTA subways, lamp posts, you name it," explained Atchu! (2012). "The first action was on Valentine's Day, when we brought a Queen Size bed to Washington Square Park and simply laid there on the bed, with strangers, flowers, cardboard signs and friends." "At first, the bed was inside the dry fountain. ... When the wheelchair movement arrived though, they could not join us in the bed, because the wheelchairs could not cross to the middle of the fountain. So we pulled a mic-check, using the Occupy styled human microphone, asking everyone to help, and carried the bed outside the fountain and they were able to join us," recalled Atchu! Like most good plays, everyone was invited to participate, lowering the threshold so everyone could join. The purpose of the working group was "to lower the bar of advocacy, activism, and revolution. (...) We create our games (...) promote them online and in person, and invite others to play along. We believe revolution without fun is no revolution at all." (Revolutionary Games 2012). The group suggested that RevGames (2012) was ideally a practice, aimed at creating a space for "for people to combine revolution and game play to break down barriers that normally exist around fear of speaking out." The group and practice was a means for challenging the powers and principalities in "a non-threatening and non-violent way. RevGames looks to engage people to share, play and express themselves in fun and creative ways, sharing these games with others and building on games to push boundaries" (Revolutionary Games 2012).

Members brought a bountiful ludic spirit to countless Occupy actions, connecting individual movement participants with an often rambunctious, shared experience. On 01 May 2012, OWS celebrated May Day, International Worker's Day. Yet, instead of joining a union rally with a planned route, OWS activists took part in the Guitarmy, an open performance in which thousands of musicians marched from Bryant Park to Union Square, performing with each other. Playful, rather than humorous, the Guitarmy was fun and touching in the way it brought people together. 

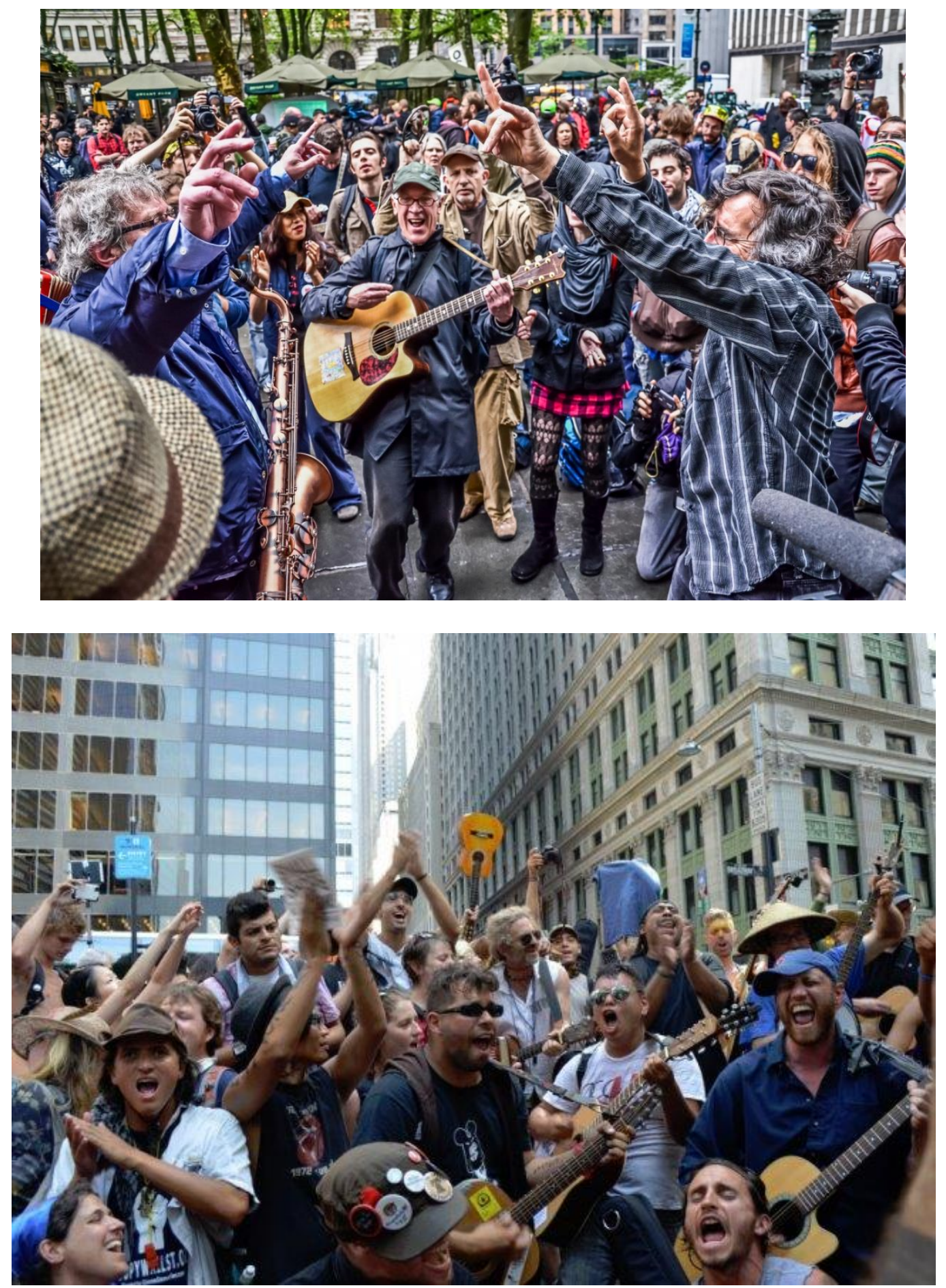

Figure 2. Guitarmy, May 2012 (C) Stacy Lanyon and Erik McGregor.

Sharing chords and lyrics, the action helped break down the line between leader, follower, spectator and participant. We headed out playing legendary political street songs such as "This Land is Your Land." Block after block we jammed to Woody Guthrie's prophetic anthem. One man marched with his cello hanging around his neck, his bow finding the melody for each song. 
The whole event was sweet as well as a little funny. Woody Allen famously struggles to play a cello in a marching band in his 1969 film Take the Money and Run. But this gentleman with the cello successfully played the instrument tied around his neck as he marched down the street. Crossing over to 30th Street, most of the rally moved into the street, celebrating the joy of connection with each other. And more and more people filled the street. Within a few minutes, police scooters started to scoot across 5th Ave. "Run like water, burn like fire" Atchu! screamed. Many of us stopped playing and scooted around. I was still picking "When the Saints Go Marching In," watching bodies collectively move to fill our public space with our unpermitted expression of wanderlust for an embodied expression of urban living. Here, those engaged in the ludic action engaged in a cat and mouse game with the police. Johan Huizinga (1950 [1938]) suggests such expressions of tension and release are core elements of play. Police scooped around again from the other side of the street and activists ran around them again. The game between protesters and police went on all the way to Madison Square Park, as a part of our May Day ritual. As we approached Union Square, police zoomed directly into a line of activists. And the crowd broke into two responses. Some surrounded the police, screaming anti-police epithets; others serenaded them with chants from "This Land." The contrast between those who sang and those who screamed was striking. Many screaming ran into conflicts with the police, risking arrest. The highly participatory performance was both engaging and disarming. This is part of what is powerful about play in social movement activity. Through such gestures, we move away from feelings of anger or resentment, toward a space with a great more affect, care, and connection with each other (Morreall 1987). Over and over, ludic activity intervenes in tense public protest situations, opening public space, while more confrontational approaches invite police backlash, often closing public space so people can no longer use it. Police understand conflict; that is a game they know how to play well. Yet, unpermitted play offers more challenges. And certainly RevGames was not the only Occupy Working group to revel in the ludic, game-like dynamics of the movement and the culture it challenged. The movement began as "fun exchange" and continued with the fun for the next year. "Wake Up Wall Street 5/ Let the Games Begin," activists declared on the movement's first anniversary on 17 September 2012.

\section{The Tax Dodgers}

Activist Kim remarked that her best memory of the first anniversary of OWS was being witness to a public clash between two playful groups: the People's Puppets of OWS, a poetry and performance art collective, were marching up the street and ran into a group calling themselves the Tax Dodgers. It was a case of "the theatrical 99\% running into the theatrical $1 \%$. The streets of NYC were EXPLODING with political art. Our time is now. We are changing the world" (Kim 2014). The next case study of this essay considers the humorous strategies of the activist group Tax Dodgers who expressed their protest by exaggeratedly favouring tax cuts and upward income distribution for the rich. 

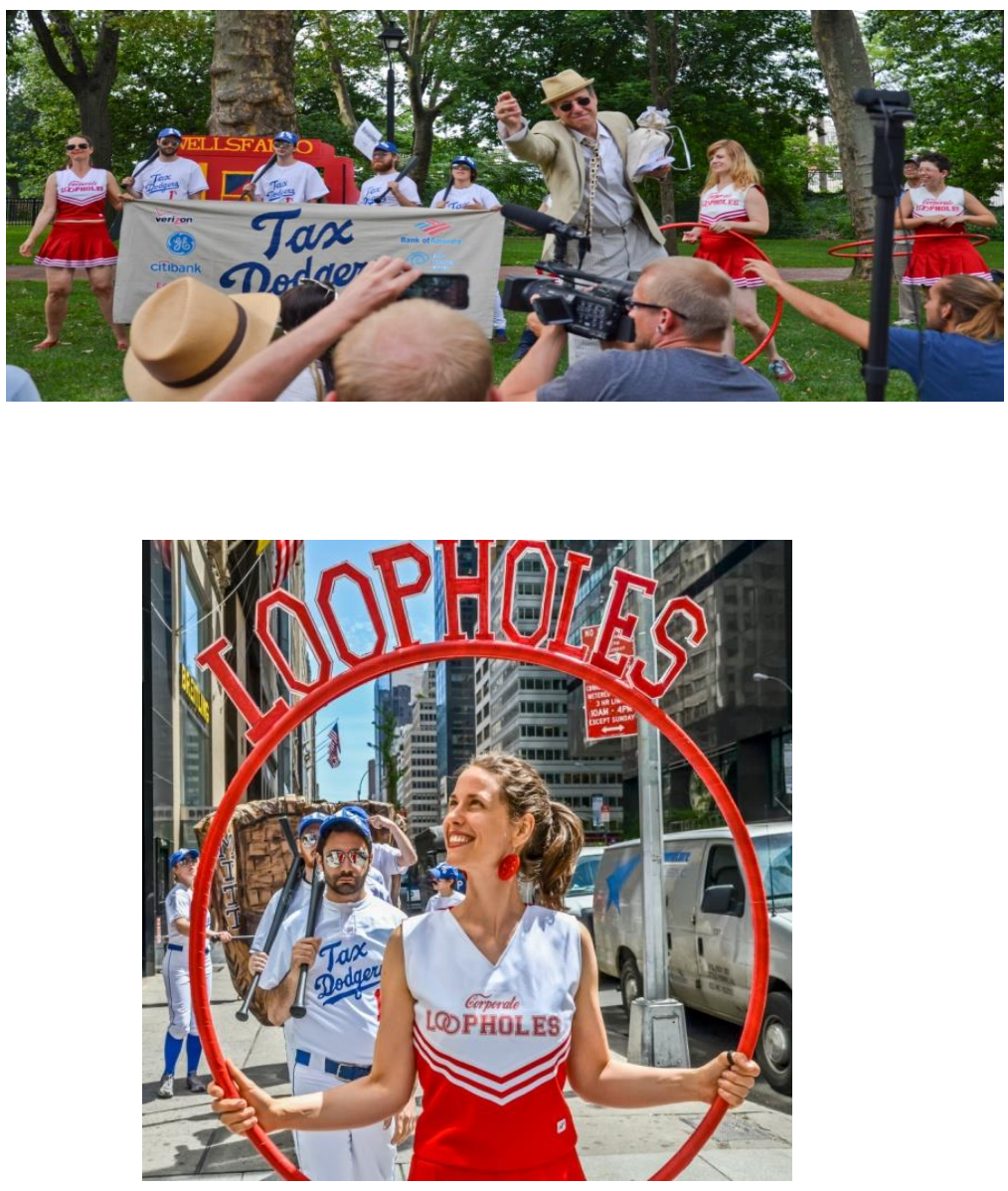

Figure 3. Tax Dodgers flaunting their loop holes on tax day 2012! (C) Erik McGregor.

Born of the OWS Performance Guild, the Tax Dodgers lampooned the ways corporations angle for their own advantages in the tax code. The association of dodging with both tax evasion as well as a baseball tactic allowed for a pun-laden combination of two meanings of dodging. With faux cheerleaders, jumping through hoola hoops, this street theatre troupe wore baseball uniforms, carrying baseball bats, and satirizing those who lobby for loopholes to reduce their tax burden (Moynihan 2012). I first saw the Tax Dodgers during an Occupy Town Square event in Central Park in 2012. Adorned in a baseball uniform with a $1 \%$ logo on her cap, my activist friend Claire carried a baseball bat, holding it like she was ready to take out a tax bracket. The next few weeks the group would make appearances at the Conservative Political Action Committee meetings as well as Occupy events. They staged their own baseball games in which they paid off the referees, highlighting the ways the so-called "one percent" write their own rules, just as the Billionaires for Bush (or Gore) revelled in the ways the super rich buy and sell democracy during the global justice movement years (Sweet 2012). The Tax Dodgers romped through Manhattan on Tax Day, singing their own version of "Take Me Out to the Ball Game". The group even brought a huge cardboard mitt, with the word "Mitt" written on it, to a fund-raiser honouring Republican nominee for president Mitt Romney as the greatest Tax Dodger of all. The group revelled in the 
"up is down", carnival quality of lampooning the limits of the US political system, as well as engaging with it (Critchley 2002; Holt 2008).

The Tax Dodgers made an appearance at the baseball Hall of Fame in Cooperstown New York, at the invitation of Tom Shieber, curator at the museum. After seeing the group in action, Shieber became interested in the ways they used baseball iconography to communicate their political message. When visitors came to the induction ceremonies for the Baseball Hall of Fame in July 2012, they found an exhibit called "Today's Game" linking baseball with the Occupy Wall Street Movement. It included one of the Tax Dodgers jerseys and caps, with the "1\%" modelled after the old Brooklyn Dodgers logo. "Baseball is a pervasive part of the American vernacular," explained Mr. Shieber. "It's a language we all speak" (Moynihan 2012).

The Tax Dodgers were part of a performative branch of the OWS movement, which sought to highlight complex challenges of the movement through street theatrics. From its first days, OWS has enjoyed a ludic disposition. During the first weekend of the movement, activists strove to transform the New York Stock Exchange into a "fun" exchange, organized by the OWS Arts and Culture working group. On 17 December 2011, OWS activists played the childhood game of hopscotch over squares marking the expanding income inequality between the $1 \%$ and the $99 \%$.

On 01 December 2011, the OWS performance guild organized a 24-hour theatre festival called Occupy Broadway in a privately owned public space (POPS) just off Broadway. Such spaces are important and paradoxical. They are closely associated with the 1960s and early 1970s, when the earliest bonus plazas, used to increase public spaces, were being built by developers who wanted the incentives offered by the city in exchange for privately owned public spaces, but could see no advantage to providing spaces that were actually usable. The POPS that have resulted are significant for several reasons. Not only do they capture the ideal of urban design in the mid-twentieth century, they were also the first experiment with private developers building public space to meet planning and zoning objectives. The privatization process that created privately owned public spaces is now widespread. New York's bonus plazas and incentive zoning regulations have become models for cities across the country (Kayden 2000; Whyte 1988). The process of privatization demonstrated so clearly in bonus plazas is representative of larger efforts to privately control public space (Shepard and Smithsimon 2011). Movement of social activists, using humour, play, and community building challenges this process of social control, even while lampooning their limitations.

\section{The Pies of March}

In March 2012, members of the New York environmental group Time's Up! teamed up with Occupy members for a theatrical meta-protest tour of Manhattan. Promotional materials for the event declared: "Beware the Ides -- make that our annual -- The Pies of March! Wait, and this year it's the Occu-Pies of March!" The Time's Up! Occu-Pies of March Bike Ride included special guests with labels prominently marked as Protesters, Media, Bankers, and Police along for the Ride. The theatrical prank highlighted the stock roles of the various players involved in the movement, from the media to the police. Taking place on 15 March 2012, we met at Astor Place Cube, Astor and Lafayette Street for a tour of Manhattan's banks. The ride included everything one could need in a protest, including a few bankers, protesters, students, police, most everyone who has suffered as result of the financial crisis, and a high-octane boost of slapstick humour. The ride ended with a round of pies being thrown at the banker, a role I had taken on, as I held forth on improving the public image of bankers and offering charitable bailouts to indebted students. 
Through such humour we find ways to reengage with the serious (Critchley 2002). The experience was both fun and cathartic. After all, who does not want to throw a pie in the face of banker? For many, the performance highlighted some of the greatest conflicts of the movement between bankers and the proletariat, the police and protesters; yet, it was fun change the rules of the game, so the bankers actually took a pie to their face instead of the mace in the face the protestors had been enduring the previous six months (Greenberg 2012).
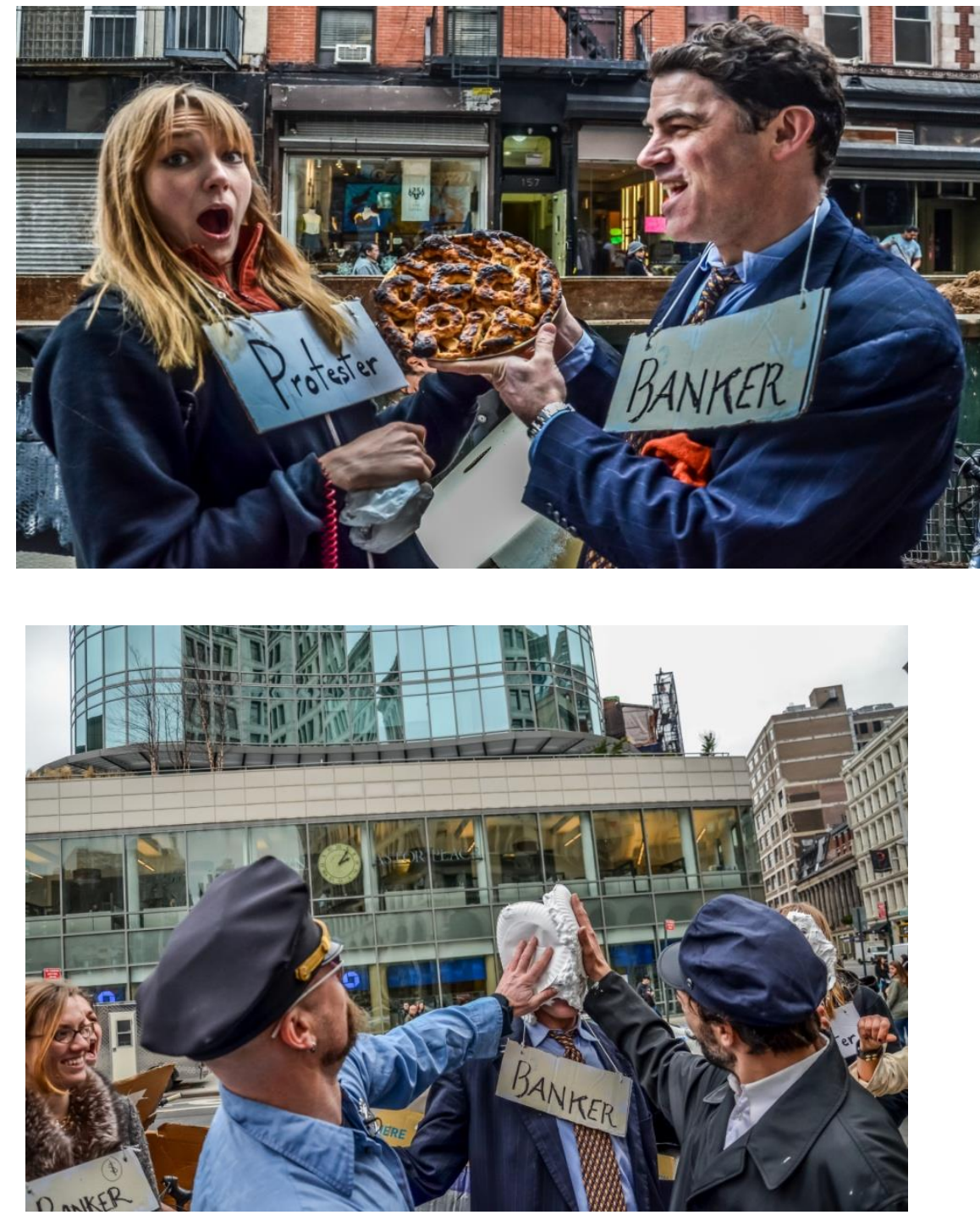

Figure 4. The Time's Up! Occu-Pies, March 2012 (c) Erik McGregor.

Monica Hunken, a Time's Up! volunteer and protester on the ride, noted, "the banks want to let us eat cake, while foreclosures rob people of their homes and strap them with debt" (2014). The reality of police repression of the movement had been a constant theme (Greenberg 2012). Police arrested activists for sitting on park benches, for chalking, using furtive eye movement, for walking the wrong way on the sidewalk and for standing in a park designated by zoning laws to be open 24 hours a day. For much of Occupy, I spent one or two days a week in jail to support 
friends put through the system for speaking out or dissenting. The Occu-Pies of March Ride highlighted the inequalities of the cat and mouse game between protestors and police, the poor and financial systems. The Pie Fight was organized to highlight a few of these underlying dynamics of the streets.

\section{Where the bike lane ends, sidewalks and experiments on bikes}

The streets are constantly changing and evolving along with our approaches to navigating them. As much as anything, play opens up in between spaces, where tensions between disorder and order, public and private, connection and social movements help us re-imagine public space. While movements aspire to transform urban experience, the streets of cities are not always so mutable. Still, play based social action helps us subvert the often monolithic narratives of urban living (Shepard and Smithsimon 2011; Tucker 2012). Yet, navigating between gamespace and our embodied experience is anything but simple. Yet a little humour and play helps to open up countless ways to see the space between the streets and sidewalk, opening up new storylines and imaginary spaces.

Together with a group of friends from Time's Up!, I participated in arranging for a group bicycle ride through the streets on 14 October 2012, looking for the few bike lanes that exist in the city, given the gaps between bike lanes and traffic routes for all traffic. To grapple with these barriers, we dressed like explorers, discoverers, sleuths, pirates, and bloodhounds, meeting at the Manhattan side of the Williamsburg Bridge to explore what to do when the bike lane ends. An activist friend, Monica, dressed up to look like Jacques Cousteau, while I dressed up as Sherlock Holmes. We brought spyglasses and binoculars to use for exploring where to go when the bike lanes end, or are obstructed, as they are coming off the Manhattan Bridge bike path into the Lower East Side of Manhattan. Leaving the bridge, we surveyed the territory, looking for an easy way across the zooming cars along Delancey Street, locating a bike lane on Clinton Street, where we zoomed at the light, riding about fifteen feet before encountering a car parked in a bike lane. Our bikes crashed into the car, whose driver was not amused to find a bunch of explorers who'd pulled out magnifying glasses to analyse what exactly was parked in our designated bike lane.

"What are you doing? Don't touch my car?" the driver screamed at us.

"What is this and what is it doing parking in a bike lane?" I asked. "It does not look like a bike." Pulling out a magnifying glass, a few of us inspected the car, crawling under it, before careening away, feeling a sense of pleasure at simply facing a driver in the solidarity of a group of friends and fellow riders. Huizinga (1950 [1938]) suggests that a tension and release is part of the embodied experience of play. It certainly felt that way as we navigated between construction, cars, and people in the lanes. "The ideal public space for play promotes innovation, experimentation, the transformation of categories, and the renegotiation of boundaries," notes Kenneth Tucker (2012: 83). While bike lanes may not be ideal places for play, they are public spaces. Through ludic adventures, this group of cyclists temporarily transformed these contested spaces into places of health, hopes, and possibilities for a sustainable city without cars. Such play opens up spaces, where we daydream, hope and imagine something else (Huizinga, 1950 [1938]; Morreal 1987).

"I had a beautiful dream a month ago," confessed Atchu!, "having absolutely no roads for cars anymore, an amazing subway network only, and above the ground, bike lanes, trees, art-play spaces, homes, grandpa shops" (2012). Many of us have had those dreams. As the city encounters more and more of the effects of global warming, floods, hurricanes and congestion, non-polluting 
transportation offers the hope for a different more sustainable model of urbanism. Bikes we used to play with as kids offer means with which to transform cities, making them better spaces. Through bike lane liberation, play helps us rethink what these lanes were drawn there for in the first place. Such "play mediates social practices and creates new spaces for rethinking and experiencing social life," notes Tucker. "It is intertwined with fantasy and imagination... This playfulness creates not just new subject positions but also novel forms of communication and ways of experiencing the world" (2012: 83). In this way, ludic social action helps us engage in non-alienating authentic experience rather than labour as we attempt to turn the often hegemonic system of traffic flow, parking, cars, and fossil fuels on their heads, making way for more sustainable models of urbanism.

\section{Discussion on play, games, and Occupy}

For much of the first year of the Occupy Movement of rides, actions, and conversations, the movement came together and sustained itself through gestures of care, mutual aid, direct action, theatre, humour and a jigger of play. In October 2011, the movement defended against a police raid and eviction planned for Zuccotti Park. Members of Time's Up! joined the defence, staying through the night, only leaving for the Blarney Stone, a pub near Zuccotti Park when it started to rain. There we grappled with questions about what the encampment could mean for a society increasingly incapable of creating a space for many to find work, shelter, or access to public space. And the group of friends eventually wandered back to the park where we slept for a few more hours in a bundle of bodies, huddling to shelter itself from the rain and the hard concrete.

Those involved in Time's Up! and OWS often discussed the importance of play. What did play have to do with the topsy-turvy organizational structure of the movement? "Carnival is what power is," explained Talmadge Wright (2011), a sociologist from Loyola, pointing to the up is down, down is up quality of the subversive protests. The play element would be important for such a movement, helping expand social eros among bodies of lovers and comrades. It is part of a moving beyond militancy towards something harder to grapple with or control. "Play is serious and frivolous. You don't know where it is coming from," explained Wright (2011), relating his point to the transgressive nature of the OWS. This is part of why the movement's enigmatic lack of clear demands remained dynamic and perplexing. The satirical newspaper The Onion pointed out that part of what the media wants from Occupy Wall Street is a set of demands it could ignore. Instead, a stream of messages relating to income inequality flew out to the world from the encampment every night. Elites did not know if the movement was accelerating or exiting. There is no clear beginning or end of such an approach. The movement's anti-corporatist power built on an echo chamber of ideas, reverberating through stories produced by the journalists who visit, the multiple tweets, and the live feed echoing out into the world. And the message connected viewers and participants from couches to streets, rioters to liberal reformers, across ideas and points of reference. In practice, the movement helped demonstrate the need for a public commons open to call. Here, public space creates room for a commons where people care, for mutual aid, and political debate unavailable in other venues.

Part of what made the movement so vital was its emphasis on place where people built a community of resistance. Here people navigate between marginalized spaces where they transform them into pleasure spaces, all the while steering clear of functional spaces, such as shelters, followed by displacement. The appeal of the ludic quality of these protests is an alternative to the prison-like coldness of the institutions our system builds to warehouse the poor 
and homeless (Wright 1997; 2011). These movements lay bare the claim that there are other ways of being in the world, other kaleidoscopes. There are other stories of place, time and myth, foundational narratives composing the universe where players execute their moves, when it is their turn to play, argues Atchu! (2012).

"We are certain that communities of joy will emerge from our struggle," read one of the zines on anarchist basics I picked up at the park. To a great degree, Zuccotti Park had been transformed into a space where people connected, dreamed and imagined something else. It is also a space in which movement actors faced eviction after eviction by storms, police, and regimes of the normal. The loss of these spaces left the body isolated, with players back to navigating between functional, pleasure, marginalized, and community spaces. Tracing lines between these spaces, the movement takes on a nomadic, rhizomatic quality. Here ideas zig-zagged between people and network, public and private spaces linking previously separate ways of looking at living and being (Longman 2011).

Witnessing OWS, it is hard not to imagine that the time of the tribes, collective efforts based on networks, has not come (Maffesoli 1996). These tribes of friends practice a play-based politics that challenges us to imagine a world beyond work and means of necessity (Morreall 1987). Such thinking invites us to grapple with questions about the very nature of play, work, humour, organization, and the problem of unemployment.

Activists often refer to Huizinga's idea of homo ludens as an answer to the crisis of homo economicus in the present global regime. In play, people find a way to create a new world with their own sweat, equity, and collaboration. These play-based strategies of community building use humour to expand public space. The mutual aid models taking shape in spaces such as OWS suggest many are already actively creating new models of being, merely working or surviving. Models of mutual aid and ludic expression seen in OWS respond to a growing sense of alienation and repression. This abundant model opens spaces for connection not seen in more alienated capitalist social arrangement; it supports alternative values, offering ways to create these new forms of work, play, innovation, and experimentation. Here the movement's rejection of work offers a new way of engaging a social world born of play, experimentation, gifting, inclusion, and sustainability. Play helps us imagine a different kind of social order, based on egalitarian, convivial social relations, which extend beyond means of necessity, away from work and hierarchical modes of social organization.

\section{Concluding thoughts and questions about gamespace}

There is certainly an "all the world's a stage" quality to the games, pranks, bike rides, and performances described in this essay; from this lens, we really are all players, as friends become actors capable of acting up together. But to what end? What connects Revolutionary Games, the Tax Dodgers and the Time's Up! bike rides presented here? These projects all suggest there are ways to playfully imagine alternatives and critique the status quo. Each case example points to ways to change the rules of the game. With each, humour is a resource for social movement engagement; it adds vitality to the process of social change. Without humour, the possibilities for social change are limited. Through the humour inherent to play, those involved are all invited to participate in the game of social change. These are gamespaces where players practice nonalienating humanity, experimenting with new ways building community outside of reified structures. For many involved in contemporary organizing, play has helped us expand social networks and participatory politics. Here, new forms of media, including cell-phones and social 
media have transformed means of political participation, making entry easy and fun, easing the digital divide which once separated people and communities (Chalko 2008). In this way, games and social media help us challenge repressive social systems and mechanisms of social control.

Paradoxically, games also reinforce them, forming a world where it is hard to move outside the panopticon of gamespace (Turkle 2011; Wark 2007). As the article makes such a strong case for play as a means to disrupt control, this counterview bears explanation. To do so, a distinction has to be made between competitive and non-competitive games, those we play by ourselves and those (video games) we play alone, with others, or in alienation (Turkle 2011). Each game offers the possibility for paradox, for both support and or isolation (Wright 2011). When games help us elude systems of control they can be seen as liberatory, yet just as often, game play is commodified and reified, especially when competitive formalized games emulate features of high capitalism. Yet, as the Surrealists pointed out, this need not be the case with modern games. There are other non-competitive games to play. The question remains: are games and play a means to better the world or an extension of the mass surveillance and a safety valve which allows for a brief respite from and eventual return to the status quo? Games are part of the tools of this system; they are also a means of resistance. Our friends are players and sometimes pawns within this process. While they are anything but neutral, in the end, it is what we do as we play the game. It is the jokes we all tell along the way that help us see the game in new ways. There is nothing apolitical in games of power. Games and play are anything but neutral. Can we hijack them, remaking them for own purposes? It depends on which jokes we tell. Can we laugh at both those in power and ourselves? With a little humour, we are all invited to change the rules of the game.

\section{References}

Atchu! (2012). Personal correspondence with the author.

Bogad, L.M. (2005). Electoral Guerrilla Theatre: Radical Ridicule in Social Movements. New York: Routledge.

Chalko, M. (2008). Portable Communities: The Social Dynamics of Online and Mobile Connectedness. New York: State University Press of New York.

Critchley, S. (2002). On Humour. London: Routledge.

Duncombe, S. (2007). Dream. New York: New Press.

Ellis, C and Bochner, A.P. (2000). 'Autoethnography, personal narrative, reflexivity: Researcher as subject', in Denzin, N. and Lincoln, Y. (eds.), The Handbook of Qualitative Research. $2^{\text {nd }}$ Edition. Thousand Oaks, Ca.: Sage, pp. 733-768.

Graeber, D. (2011). 'Interview with David Graeber', by Evans, E. and Moses, J., The White Review, December 2011. Available online: http://www.thewhitereview.org/interviews/interview-with-david-graeber/ [Accessed 30 September 2014].

Greenberg, M. (2012). 'New York: The police and the protesters', New York Review of Books. 11 October 2012, LIX (15), pp. 58-61.

Holt, J. (2008). Stop Me If You've Heard This: A History and Philosophy of Jokes. New York: Norton.

Hunken, M. (2014). Personal correspondence with the author.

Huizinga, J. (1950 [1938]). Homo Ludens: A Study of the Play Element in Culture. Boston: Beacon. 
Kayden, J.; Municipal Arts Society; New York Department of City Planning (2000). Privately Owned Public Spaces: The New York City Experience. New York: John Wiley.

Kim (2014). Personal correspondence with the author.

Longman, L. (2011). "Visions of play, pleasure and technology in a sustainable post capitalist society." Panelist at the meeting of the Association of Humanist Sociologists. Chicago, October 152011.

Lukács, G. (1968). History and Class Consciousness: Studies in Marxist Dialectics. Boston: MIT Press.

Marcuse, H. (1969). 'Repressive tolerance' in Wolff, R.P., Moore, B. Jr., and Marcuse, H., A Critique of Pure Tolerance. Boston: Beacon Press, pp. 95-137.

Maffesoli, M. (1996). Time of the Tribes: The Decline of Individualism in Mass Society. Thousand Oaks, CA: Sage.

Morreall, J. (1987). The Philosophy of Laughter and Humor. New York: State University Press of New York.

Morreall, John (2012). 'Philosophy of humor'. Stanford Encyclopedia of Philosophy. Available online: http://plato.stanford.edu/entries/humor/\#Inc [Accessed 4 September 2015].

Moynihan, C. (2012). 'Protest gets a pedestal among baseball's greats', New York Times. 23 July 2012, p. A18. Available online: http://www.nytimes.com/2012/07/23/nyregion/occupy-wallstreet-protest-gets-a-pedestal-among-baseballs-greats.html?_r=0 [Accessed 30 September 2014].

Revolutionary Games (2012) 'Who are you in bed with for V-Day?', New York Arts Magazine, 11 February 2012. Available online: http://www.nyartsmagazine.com/?p=8895 [Accessed 30 September 2014].

Sanders, B. (1996). Sudden Glory: Laughter as Subversive History. Boston, MA: Beacon.

Schechner, R. (2002). Performance Studies: An Introduction. New York: Routledge.

Shepard, B. (2009). Queer Political Performance and Protest: Play, Pleasure, and Social Movement. New York: Routledge.

Shepard, B. (2011). Play, Creativity and Social Movements. New York, NY: Routledge.

Shepard, B. and Smithsimon, G. (2011). The Beach Beneath the Streets: Contesting New York's Public Spaces. New York: State University Press of New York.

Sweet, D. (2012). 'Inside the Tax Dodgers', 01 August 2012. Available online: http://crooksandliars.com:8080/diane-sweet/inside-tax-dodgers [Accessed 30 September 2014].

Trahar, S. (2009). 'Beyond the story itself: Narrative inquiry and autoethnography in intercultural research in higher education', Forum: Qualitative Social Research 10 (1). Available online: http://www.qualitative-research.net/index.php/fqs/article/view/1218/2653 [Accessed 30 September 2014].

Tucker, K. H. (2012). Workers of the World, Enjoy! Philadelphia, Pa: Temple University Press.

Turkle, S. (2011). Alone Together: Why We Expect More from Technology and Less From Each Other. New York: Basic Books.

Wark, M. (2007). Gamer Theory. Boston, MA: Harvard University Press.

Whyte, W. H. (1988). City: Rediscovering the Center. New York: Doubleday.

Wright, T. (1997). Out of Place: Homeless Mobilization, Subcities and Contested Landscapes. Albany, NY: SUNY Press. 
Wright, T. (2011). 'Visions of play, pleasure and technology in a sustainable post capitalist society', Panelist at the meeting of the Association of Humanist Sociologists. Chicago, October 152011.

Writers for the 99\%. (2011). Occupying Wall Street: the Inside Story of an Action that Changed America. OR Books: New York.

Z, Mickey (2014). Occupy This Book. New York: NY Sullivan Street Press. 